
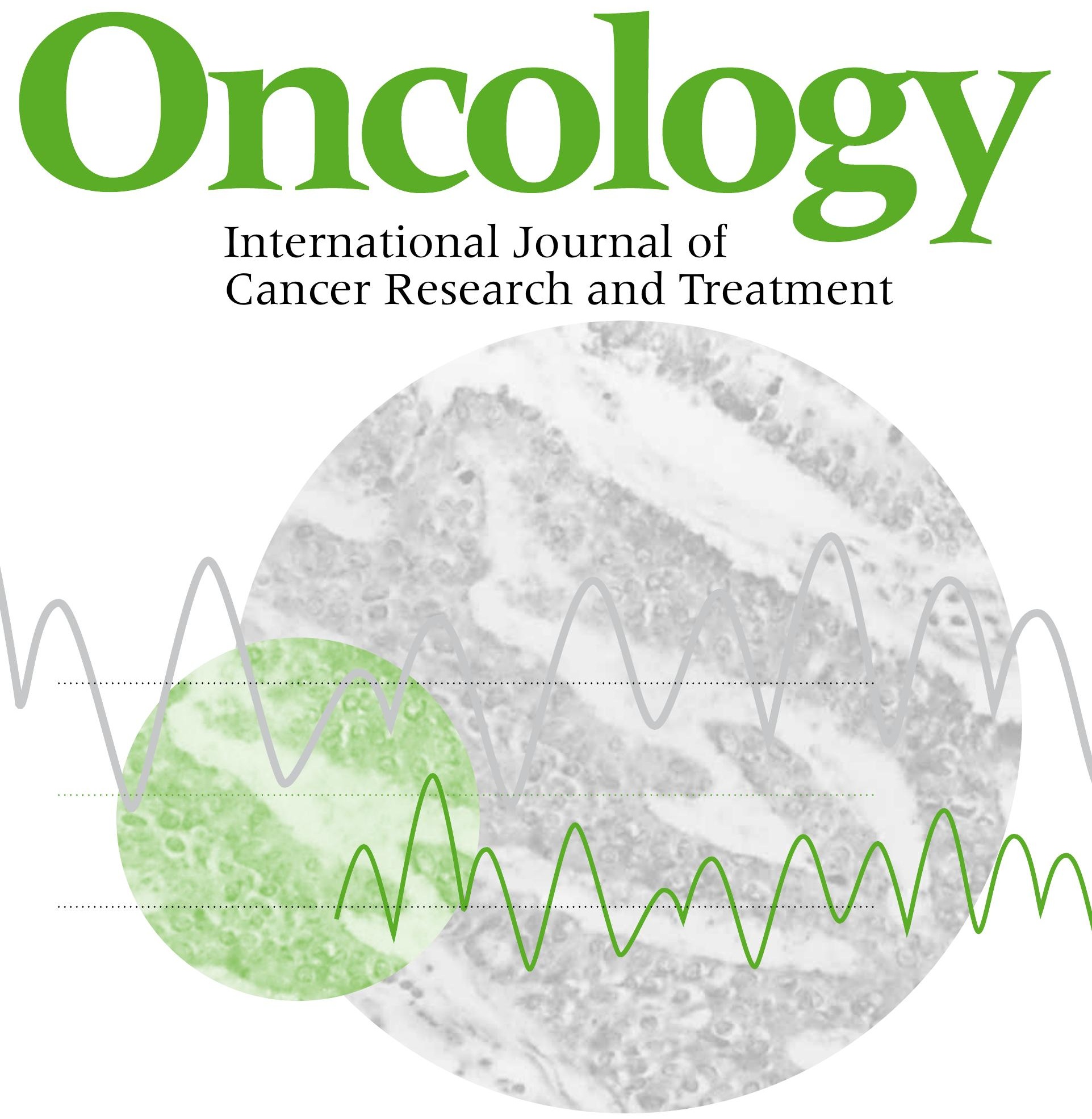


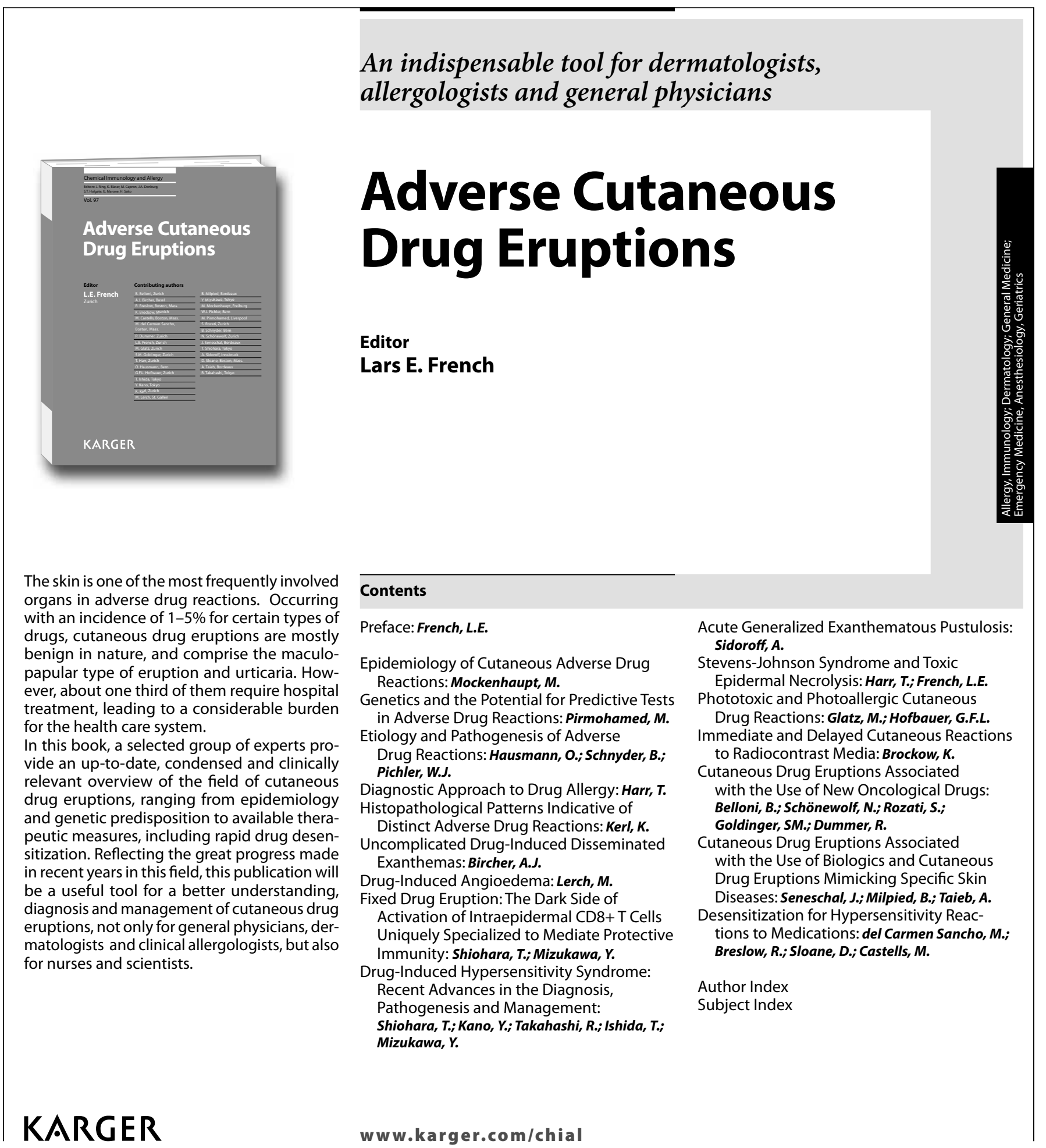

Chemical Immunology and Allergy, Vol. 97

Series Editors: Ring, J. (Munich); Blaser, K. (Davos);

Capron M. (Lille); Denburg, J.A. (Hamilton); Holgate, S.T.

(Southampton); Marone, G. (Naples); Saito, H. (Tokyo) ISSN 1660-2242 / e-ISSN 1662-2898

\section{Adverse Cutaneous Drug Eruptions}

Editor: French, L.E. (Zurich)

XIV + 240 p., 43 fig., 30 in color, 34 tab., hard cover, 2012

CHF 198.- / EUR 165.- / USD 233.00

Prices subject to change

EUR price for Germany, USD price for USA only

ISBN 978-3-8055-9970-2

e-ISBN 978-3-8055-9971-9

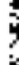

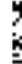

An indispensable tool for dermatologists,
allergologists and general physicians

\section{Adverse Cutaneous Drug Eruptions}

Editor

Lars E. French

\section{Please send: __ copy/ies}

Postage and handling free with prepayment

\section{E}

Please charge to my credit card

- $\square$ American Express $\square$ Diners

$\square$ MasterCard

- Card No.

0

ర Exp. date:

- CVV/CVC

(3 digits in the signature field on the back of Visa and MasterCard)

$\square$ Check enclosed $\square$ Please bill me

Orders may be placed with any bookshop, subscription agency, directly with the publisher or through a Karger distributor.
Fax: +41 613061234

S. Karger AG, P.O. Box, CH-4009 Basel (Switzerland) E-Mail orders@karger.ch, www.karger.com

Name/Address:

Date: 


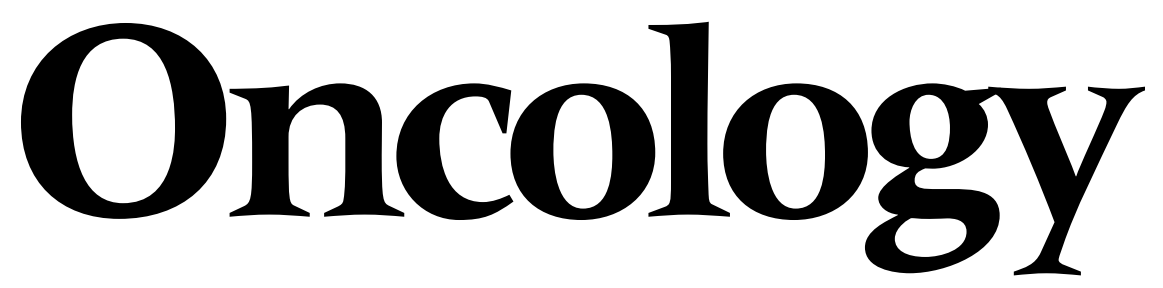

International Journal of Cancer Research and Treatment

Founded 1948 as 'Oncologia' by H.R. Schinz

Continued by V. Richards (1967-1975), H. Wrba (1976-1992), P.P. Carbone (1993-2002),

D.L. Trump (2002-2007)

\section{Editor-in-Chief}

M. Markman, Philadelphia, Pa.

\section{Associate Editor}

P. Dufour, Strasbourg

Regional Editor Japan

O. Hino, Tokyo

\section{Editorial Board}

A.B. Benson, Chicago, Ill. A. Chang, Singapore

A.L. Cheng, Taipei

J.F. Cleary, Madison, Wisc.

M.S. Ernstoff, Lebanon, N.H.

M. Fakih, Ann Arbor, Mich.

J.J. Grau, Barcelona

H. Gronemeyer, Illkirch

D.F. Hayes, Ann Arbor, Mich.

C.S. Johnson, Buffalo, N.Y.

M.J. Kelley, Durham, N.C.

P.J. Loehrer, Indianapolis, Ind.

J.R. Marshall, Buffalo, N.Y.

S. Monfardini, Milan

R. Nagler, Haifa

R. Ohno, Nagoya

B. Pestalozzi, Zurich

H.M. Pinedo, Amsterdam

E.A. Repasky, Buffalo, N.Y.

A. Semczuk, Lublin

C.N. Sternberg, Rome

R. Stupp, Lausanne

M.S. Tallman, Chicago, Ill.

S. Tanaka, Hiroshima

M. Tian, Houston, Tex.

D.L. Trump, Buffalo, N.Y.

T. Wiegel, Ulm

W. Yasui, Hiroshima

H. Zhang, Hangzhou City 


\section{Oncology}

\section{Submission}

Original papers and reviews written in English are considered for publication. Manuscripts should be submitted to 'Oncology' online. For specific instructions on how to prepare a manuscript for submission, you are encouraged to view the guidelines at www. karger.com/ocl, where you will also find a link to the Submission Website. Names, postal and e-mail addresses of at least four experts in the appropriate area of research must accompany each manuscript. Selected scientists will be invited to act as referees. Referees suggested should not be from the same institution as the author and should have expert knowledge of the subject. Should you have any problems with your submission, please contact:

Dr. M. Markman
S. Karger AG
Editorial Office 'Oncology'
P.O. Box
CH-4009 Basel (Switzerland)
Tel. +41 613061359
Fax +4161306 1434
E-Mail ocl@karger.ch

Mailing address for courier deliveries only: Allschwilerstr. 10

CH-4055 Basel (Switzerland)

\section{Conditions}

All manuscripts are subject to editorial review. Manuscripts are received with the explicit understanding that they are not under simultaneous consideration by any other publication. The editors reserve the right to improve style and, if necessary, return the manuscript for rewriting to the author. Submission of an article for publication implies the transfer of the copyright from the author to the publisher upon acceptance. Accepted papers become the permanent property of 'Oncology' and may not be reproduced by any means, in whole or in part, without the written consent of the publisher. It is the author's responsibility to obtain permission to reproduce illustrations, tables, etc. from other publications.

All manuscripts originating from non-English speaking countries must be revised by a professional linguistic reviewer and it must be evident from the covering letter that this has been done.

The editor reserves the right to reject papers based on priorities and space availability in the journal.

\section{Conflicts of Interest}

Authors are required to disclose any sponsorship or funding arrangements relating to their research and all authors should disclose any possible conflicts of interest. Conflict of interest statements will be published at the end of the text of the article.

\section{Ethical and Legal Prerequisites}

Manuscripts involving examinations of human subjects must include a statement that the trial protocol has been approved by an ethical committee and thus meets the standards of the Declaration of Helsinki in its revised version of 1975 and its amendments of 1983, 1989, and 1996 [JAMA 1997;277:925-926]. Accordingly, the subject's informed consent has to be mentioned in the manuscript. Information suitable to reveal the subject's identity is to be avoided.

\section{Categories of Manuscripts}

Reviews are comprehensive, state-of-the-art analyses and investigations of important clinical problems. Reviews must include a critical discussion of the reported data and give a clear conclusion with the potential impacts on the standard of care. Reviews may be invited by the Editor, or they may be unsolicited submissions. Reviews are not subject to page charges. The maximum length of manuscripts in this category will be 5,000 words for text and tables (a table $=250$ words per page), with a maximum of 5 tables and 50 references.

Clinical Studies and Clinical Translational Research Articles are full-length research papers which will be considered for the journal. These articles cover topics relevant to clinical and translational studies in all oncological fields. Note that manuscripts presenting laboratory-based research efforts must address a clinically relevant issue (Translational Research).

Short Communications will focus on descriptions of important toxicities of novel therapies and highly unique oncology-related medical management issues. The maximum length of manuscripts in this category will be 1,000 words.

Clinical Trial Notes are designed for brief discussions of clinical trials, with a particular focus on phase 1 , phase $1 / 2$, and phase 2 studies. Priority in this section will not be for studies with a 'positive result', but rather for well-conceived and conducted clinical research efforts. The maximum length of manuscripts submitted in this category will be 1,500 words, with a maximum of 2 tables and 1 figure. The paper should be divided into four sections: Introduction, Methods, Results, Discussion. Note that all manuscripts submitted in this category will undergo rapid review for acceptance or rejection.

Reducing the Worldwide Burden of Cancer are country reports describing a variety of regional, national or international efforts that focus on the unique aspects of the epidemiology of cancer, and the delivery of educational messages, preventive services, and oncology-related care within the developing world. Papers submitted for this section benefit from a higher quota of free pages. There are no page charges for papers of 8 or fewer printed pages. Each additional complete or partial page is charged to the author at CHF 325.00 .

Editorials provide comments on papers published in Oncology. They are usually invited by the Editor.

\section{Arrangement}

Title page: The first page of each paper should indicate the title, the authors' names, the institute where the work was conducted, and a short title for use as running head.

Full address: The exact postal address of the corresponding author complete with postal code must be given at the bottom of the title page. Please also supply phone and fax numbers, as well as e-mail address.

Key words: Please supply 3-10 key words in English that reflect the content of the paper.

Abstract: Papers submitted to the sections Reviews, Clinical Studies, Clinical Translational Research Articles, Clinical Trial Notes and Reducing the World- wide Burden of Cancer need an abstract of up to 200 words. Abstracts are recommended, but optional, for Short Communications and Editorials. Abstracts of papers submitted for publication that have clinical implications using human materials should be structured with subheadings as follows: Objective(s), Methods, Results, Conclusion(s).

Footnotes: Avoid footnotes. When essential, they are numbered consecutively and typed at the foot of the appropriate page.

Tables and illustrations: Tables and illustrations (both numbered in Arabic numerals) should be prepared on separate pages. Tables require a heading and figures a legend, also prepared on a separate page. Due to technical reasons, figures with a screen background should not be submitted. When possible, group several illustrations in one block for reproduction ( $\max$. size $180 \times 223 \mathrm{~mm}$ ) or provide crop marks. Each illustration must be labelled with its number and the first author's name. $\mathrm{B} / \mathrm{w}$ half-tone and color illustrations must have a final resolution of $300 \mathrm{dpi}$ after scaling, line drawings one of 800-1,200 dpi. Figure files must not be embedded in a document file but submitted separately (see detailed instructions on the Submission Website at www.karger.com/ocl).

\section{Color illustrations}

Online edition: Color illustrations are reproduced free of charge. In the print version, the illustrations are reproduced in black and white. Please avoid referring to the colors in the text and figure legends. Print edition: Up to 6 color illustrations per page can be integrated within the text at CHF 800.- per page.

\section{References}

In the text identify references by Arabic numerals [in square brackets]. Material submitted for publication but not yet accepted should be noted as 'unpublished data' and not be included in the reference list. The list of references should include only those publications which are cited in the text. Do not alphabetize; number references in the order in which they are first mentioned in the text. The surnames of the authors followed by initials should be given. There should be no punctuation other than a comma to separate the authors. Preferably, please cite all authors. Abbreviate journal names according to the Index Medicus system. Also see International Committee of Medical Journal Editors: Uniform requirements for manuscripts submitted to biomedical journals (www. icmje.org).

Examples

(a) Papers published in periodicals: Chatel J-M Bernard H, Orson FM: Isolation and characterization of two complete Ara h 2 isoforms cDNA. Int Arch Allergy Immunol 2003;131:14-18

(b) Papers published only with DOI numbers:

Theoharides TC, Boucher W, Spear K: Serum interleukin-6 reflects disease severity and osteoporosis in mastocytosis patients. Int Arch Allergy Immunol DOI: $10.1159 / 000063858$

(c) Monographs: Matthews DE, Farewell VT: Using and Understanding Medical Statistics, ed 3, revised. Basel, Karger, 1996.0

(d) Edited books: Cochrane AL, Ricardo SD: Oxidant stress and regulation of chemokines in the develop-
KARGER

Fax +41 613061234

E-Mail karger@karger.ch

www.karger.com 
ment of renal interstitial fibrosis; in Razzaque MS, Taguchi T (eds): Renal Fibrosis. Contrib Nephrol. Basel, Karger, 2003, vol 139, pp 102-119.

Reference Management Software: Use of EndNote is recommended for easy management and formatting of citations and reference lists.

\section{Digital Object Identifier (DOI)}

S. Karger Publishers supports DOIs as unique identifiers for articles. A DOI number will be printed on the title page of each article. DOIs can be useful in the future for identifying and citing articles published online without volume or issue information. More information can be found at www.doi.org.

\section{Supplementary Material}

Supplementary material is restricted to additional data that are not necessary for the scientific integrity and conclusions of the paper. Please note that all supplementary files will undergo editorial review and should be submitted together with the original manuscript. The Editors reserve the right to limit the scope and length of the supplementary material. Supplementary material must meet production quality standards for Web publication without the need for any modification or editing. In general, supplementary files should not exceed $10 \mathrm{MB}$ in size. All figures and tables should have titles and legends and all files should be supplied separately and named clearly. Acceptable files and formats are: Word or PDF files,
Excel spreadsheets (only if the data cannot be converted properly to a PDF file), and video files (.mov, .avi, .mpeg).

\section{Author's Choice ${ }^{\mathrm{TM}}$}

Karger's Author's Choice ${ }^{\mathrm{TM}}$ service broadens the reach of your article and gives all users worldwide free and full access for reading, downloading and printing at www.karger.com. The option is available for a onetime fee of CHF 3000.-, which is a permissible cost in grant allocation. More information can be found at www.karger.com/authors_choice.

\section{NIH-Funded Research}

The U.S. National Institutes of Health (NIH) mandates under the NIH Public Access Policy that final, peer-reviewed manuscripts appear in its digital database within 12 months of the official publication date. As a service to authors, Karger submits the final version of your article on your behalf to PubMed Central. For those selecting our premium Author's Choice $^{\mathrm{TM}}$ service, we will send your article immediately upon publishing, accelerating the accessibility of your work without the usual embargo. More details on NIH's Public Access Policy is available at http:// publicaccess.nih.gov/policy.htm

\section{Self-Archiving}

Karger permits authors to archive their pre-prints (i.e. pre-refereeing) or post-prints (i.e. final draft post-ref- ereeing) on their personal or institution's servers, provided the following conditions are met: Articles may not be used for commercial purposes, must be linked to the publisher's version, and must acknowledge the publisher's copyright. Authors selecting Karger's Author's Choice ${ }^{\mathrm{TM}}$ feature, however, are also permitted to archive the final, published version of their article, which includes copyediting and design improvements as well as citation links.

\section{Page Charges}

There are no page charges for papers of 3 or fewer printed pages (including tables, illustrations and references). Each additional complete or partial page is charged to the author at CHF 325.-. The allotted size of a paper is equal to approx. 9 manuscript pages (including tables, illustrations and references).

\section{Proofs}

Unless indicated otherwise, proofs are sent to the corresponding author and should be returned with the least possible delay. Alterations other than the correction of printer's errors are charged to the author.

\section{Reprints}

Order forms and a price list are sent with the proofs. Orders submitted after the issue is printed are subject to considerably higher prices.

\section{New edition of an essential resource!}

\section{IMRT·|GRT·SBRT \\ Advances in the Treatment Planning and Delivery of Radiotherapy}

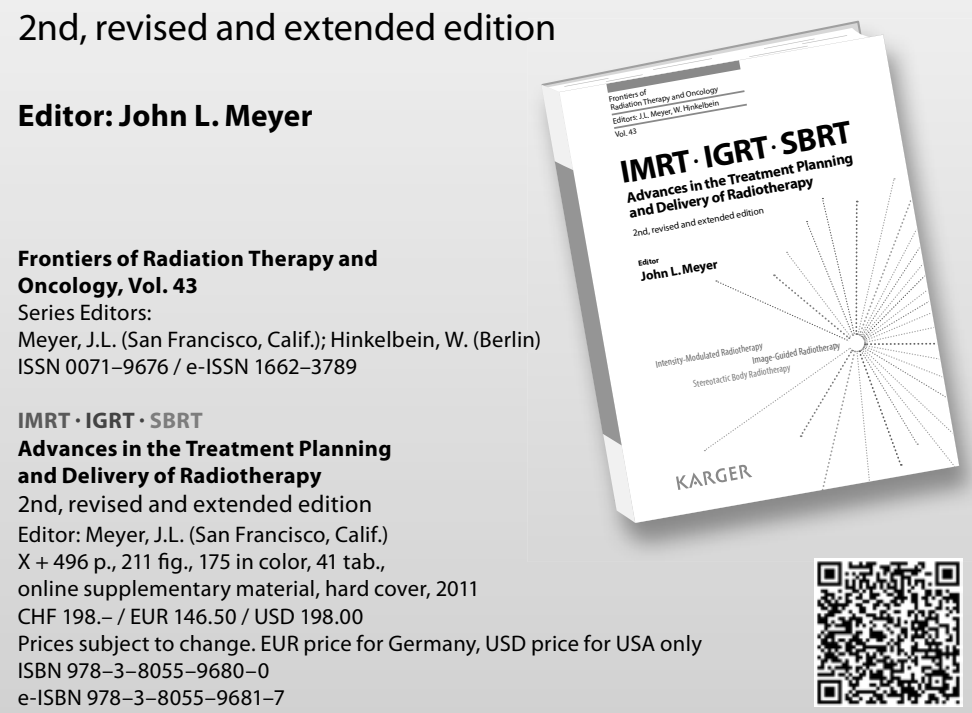

\section{Contents}

Preface

Introduction

General Concepts and Methods

Economic Perspectives

IMRT and IGRT: Intensity-Modulated and

Image-Guided Radiotherapy

IMRT: Advances in Treatment Design and Delivery IGRT: Advances in Targeting Therapy Integrating IMRT and IGRT into Treatment Delivery

IMRT and IGRT Clinical Treatment Programs Head and Neck Cancers

Thoracic Cancers

Breast Cancer

Abdominal Cancers

Lymphomas

Prostate Cancer

SBRT: Stereotactic Body Radiotherapy

SBRT Advances

Thoracic Cancers

Gastrointestinal Cancers

Genitourinary Cancers

Proton Beam Radiotherapy

Techniques and Technologies

Medical Applications and Advances

\section{KARGER}

Fax +41 613061234 E-Mail karger@karger.ch www.karger.com 


\section{Oncology}

ISSN Print Edition: 0030-2414

ISSN Online Edition: 1423-0232

Journal Homepage: www.karger.com/ocl

Publication Data: 'Oncology' is published 12 times a year. Volumes 82 and 83 , each with 6 issues, appear in 2012.

Copyright: (c) 2012 S. Karger AG, Basel (Switzerland). All rights reserved. No part of this publication may be translated into other languages, reproduced or utilized in any form or by any means, electronic or mechanical, including photocopying, recording, microcopying, or by any information storage and retrieval system, without permission in writing from the publisher or, in the case of photocopying, direct payment of a specified fee to the Copyright Clearance Center.

Disclaimer: The statements, opinions and data contained in this publication are solely those of the individual authors and contributors and not of the publisher and the editor(s). The appearance of advertisements in the journal is not a warranty, endorsement, or approval of the products or services advertised or of their effectiveness, quality or safety. The publisher and the editor(s) disclaim responsibility for any injury to persons or property resulting from any ideas, methods, instructions or products referred to in the content or advertisements.
Subscription Rates: Subscriptions run for a full calendar year. Prices are given per year. Personal subscription:

Print or Online

CHF 1546.-

EUR 1236.-

USD 1500.00

Print+Online combined CHF 1642.-

EUR 1312.-

USD 1594.00

postage and handling (added to print and print+online)

CHF 81.60 Europe, CHF 120.- Overseas

EUR 62.40

USD 112.80

Institutional subscription:

Print or Online

Print+Online combined

CHF 3090.-

EUR 2472.-

CHF 3400.-

USD 3000.00

EUR 2720.-

postage and handling (added to print and print+online)

CHF 102.- Europe, CHF 150.- Overseas

EUR 78.-

USD 141.00

Airmail surcharge: CHF 102.- / USD 96.00
Back Volumes and Single Issues: Information on availability and prices of single print issues and print or electronic back volumes can be obtained from Customer Service atservice@karger.ch.

Bibliographic Indices: This journal is regularly listed in bibliographic services, including Current Contents ${ }^{\circledR}$ and PubMed/MEDLINE.

Photocopying: This journal has been registered with the Copyright Clearance Center (CCC), as indicated by the code appearing on the first page of each article. For readers in the US, this code signals consent for copying of articles for personal or internal use, or for the personal or internal use of specific clients, provided that the stated fee is paid per copy directly to

Copyright Clearance Center Inc.

222 Rosewood Drive

Danvers, MA 01923 (USA)

A copy of the first page of the article must accompany payment. Consent does not extend to copying for general distribution, for promotion, for creating new works, or for resale. In these cases, specific written permission must be obtained from the copyright owner,

S. Karger AG, P.O. Box

CH-4009 Basel (Switzerland).
Subscription Orders:

Subscription Orders:
Orders can be placed at agencies,

bookstores, directly with the Publisher

\section{S. Karger AG}

Medical and Scientific Publishers

P.O. Box

CH-4009 Basel

Switzerland

(for courier services only:

Allschwilerstrasse 10

CH-4055 Basel)

$\mathrm{t}:+41613061111$

f: +41613061234

e: karger@karger.ch

w: www.karger.com or further Karger offices

or representatives:

\section{Germany}

S. Karger GmbH

Postfach

79095 Freiburg

Deutschland

(Hausadresse: Wilhelmstrasse 20A,

79098 Freiburg)

t: +49761452070

f: +497614520714

e: information@karger.de

w: www.karger.de

\section{Japan}

Karger Japan, Inc.

Shiba Daimon Asahi Bldg. 2F

1-2-23 Shiba Daimon

Minato-ku

Tokyo 105-0012

Japan

t: +81364356242

f: +81364356244

e: publisher@karger.jp

w: www.karger.jp

Change of Address:

Both old and new address should be sent to the subscription source.

USA

S. Karger Publishers, Inc.

26 West Avon Road

P.O. Box 529

Unionville, CT 06085

USA

Toll free: +18008285479

t: +18606757834

f: +18606757302

e: karger@snet.net

France

Librairie Médi-Sciences Sarl

36, bd de Latour-Maubourg

75007 Paris

France

t: $+33(0) 145514258$

$\mathrm{t}: \quad+33(0) 145514258$
$\mathrm{f}: \quad+33(0) 145560780$

f: +33(0) 145560780
e: librairie@medi-sciences.fr

w: www.medi-sciences.fr

Gulf Council Countries, Iran,

Middle East, North Africa, Turkey

Trans Middle East International

Distribution Co. Ltd.

KaSha

134 Queen Rania Al Abdullah Street

Jordan Trade Center Bldg. 3rd Floor

P.O. Box 2376

Amman 11953

Jordan

t: $\quad+96265153467$
f: $\quad+96265153472$

e: info@kasha.cc

w: www.KaShaonline.com
South East Asia, China and Taiwan Karger Regional Office (Malaysia) CEO Suite Kuala Lumpur Quill 7,27th Floor

Jalan Stesen Sentral 5

KL Sentral

Kuala Lumpur 50470

Malaysia

t: +60327766803

t: $\quad+60327766803$
f: +60327766999

e: service@karger.cn; r.chew@karger.cn

\section{Karger China}

10th Floor, Twin Towers (East)

B12 Jianguomenwai Avenue

Beijing 100022

China

t: +861051235033

f: +861051235122

e: service@karger.cn; r.chew@karger.cn

w: www.karger.cn

India, Bangladesh, Sri Lanka

Medscience India

Plot No. 17, Yusuf Sarai Market

B.L. Glass Building, 2nd Floor

Sri Aurobindo Marg

New Delhi 110016

India

t: +911146029633

f: +911146029634

c: +919891052128

e: medsci.india@gmail.com

\section{KARGER}

Fax +41 613061234

E-Mail karger@karger.ch

www.karger.com
(C) 2012 S. Karger AG, Basel

The Journal Home Page is available at:

www.karger.com/ocl 


\section{Contents}

See the journal website for contents

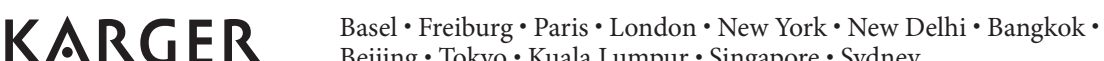
Beijing $\cdot$ Tokyo $\cdot$ Kuala Lumpur $\cdot$ Singapore $\cdot$ Sydney 


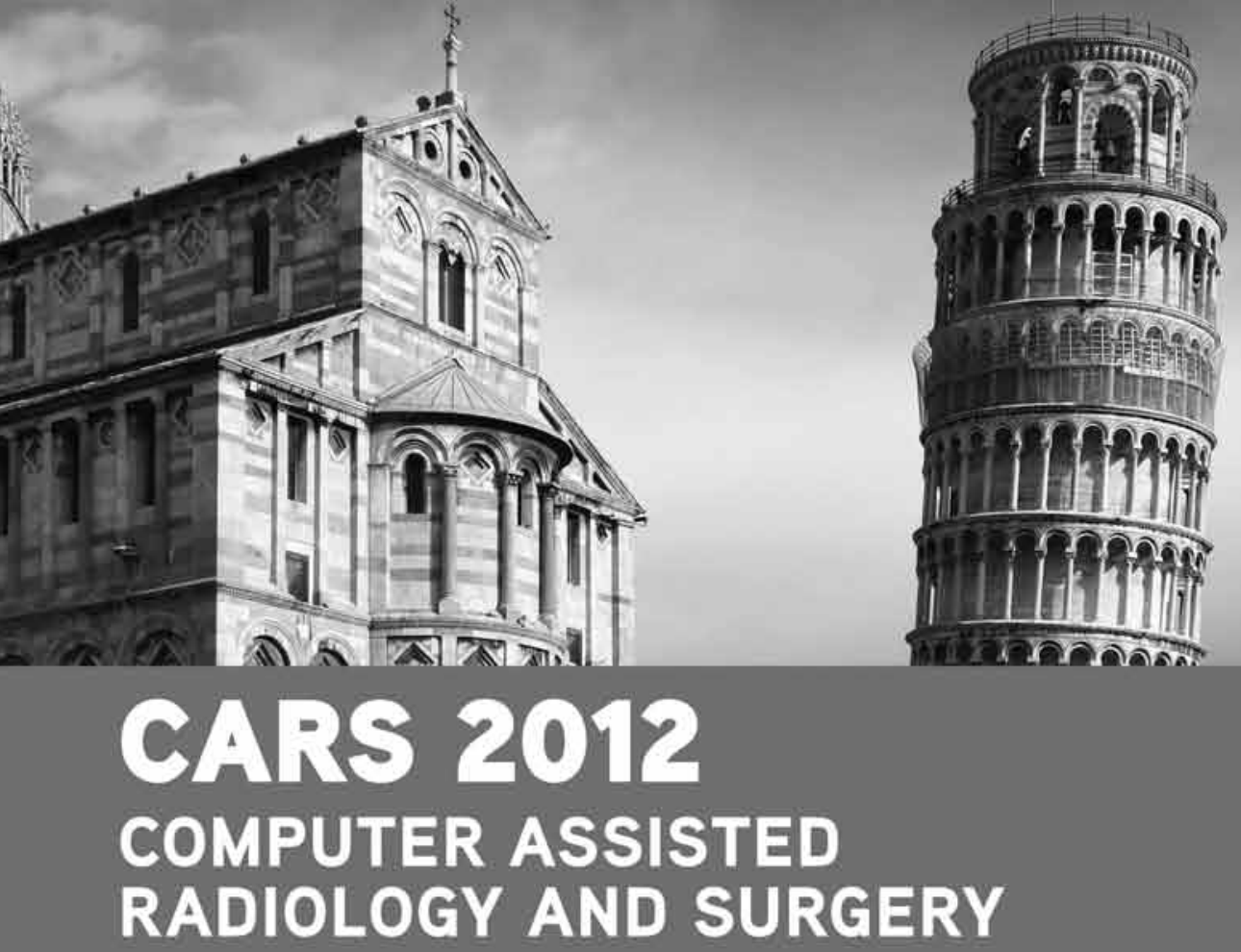

\section{$26^{\text {th }}$ International Congress and Exhibition}

\section{Main Themes}

A journal for interdisciplinary research, development and applications of image guided diagnosis and therapy

- Medical Imaging

- Computed Maxillofacial Imaging

- Image Processing and Visualization

- PACS and IHE

- Telemedicine and E-Health

- Computer Aided Diagnosis

- Computer Assisted Radiation Therapy

- Image and Model Guided Therapy

- Personalized Medicine

- Surgical Navigation

- Surgical Robotics and Instrumentation

- Surgical Simulation and Education

- Computer Assisted Orthopaedic and Spinal Surgery

- Computer Assisted Head and Neck, and ENT Surgery

- Image Guided Neurosurgery

- Minimally Invasive Cardiovascular and Thoracoabdominal Surgery

- Digital Operating Room

Deadline for abstract/paper submission: 10 th January 2012

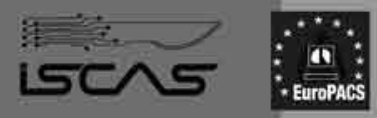

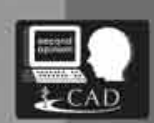

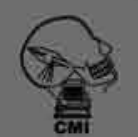

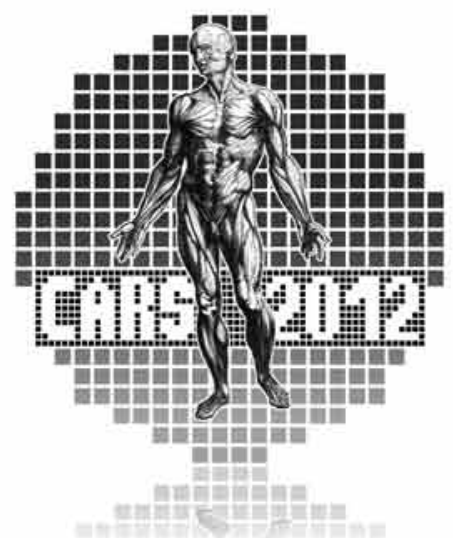

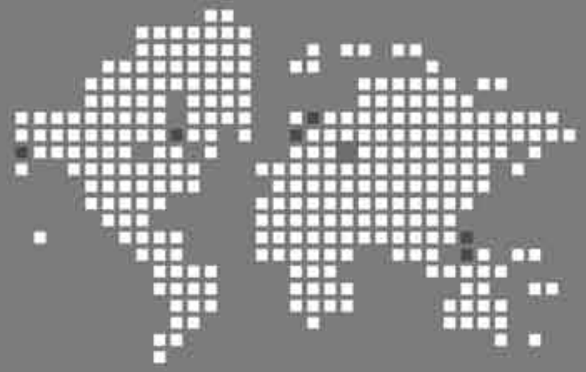

June 27-30, 2012

Pisa, Italy

\section{CARS 2012 President:}

Davide Caramella, MD (I)

$26^{\text {th }}$ International Congress and Exhibition on Computer Assisted Radiology

Chairman: Stanley Baum, MD (USA) Co-chair: Carlo Bartolozzi, MD (1)

$16^{\text {th }}$ Annual Conference of the International Society for Computer Aided Surgery President: Kevin Cleary, PhD (USA)

$30^{\text {th }}$ International EuroPACS Meeting President: Emanuele Neri, MD (I)

$14^{\text {th }}$ International Workshop on

Computer-Aided Diagnosis

Chairman: Kunio Doi, PhD (USA)

Co-chair: Ulrich Bick, MD (D)

$18^{\text {th }}$ Computed Maxillofacial

Imaging Congress

Chairman: Allan G. Farman, PhD, DSc (USA)

$13^{\text {th }}$ CARS / SPIE / EuroPACS Joint

Workshop on Surgical PACS

and the Digital Operating Room

Chairmen: Osman M. Ratib, MD, PhD (CH),

Heinz U. Lemke, PhD (D)

$4^{\text {th }}$ EPMA / IFCARS Workshop on

Personalized Medicine and ICT

Chairs: Olga Golubnitschaja, MD (D)

Heinz U. Lemke, PhD (D)

www.cars-int.org 

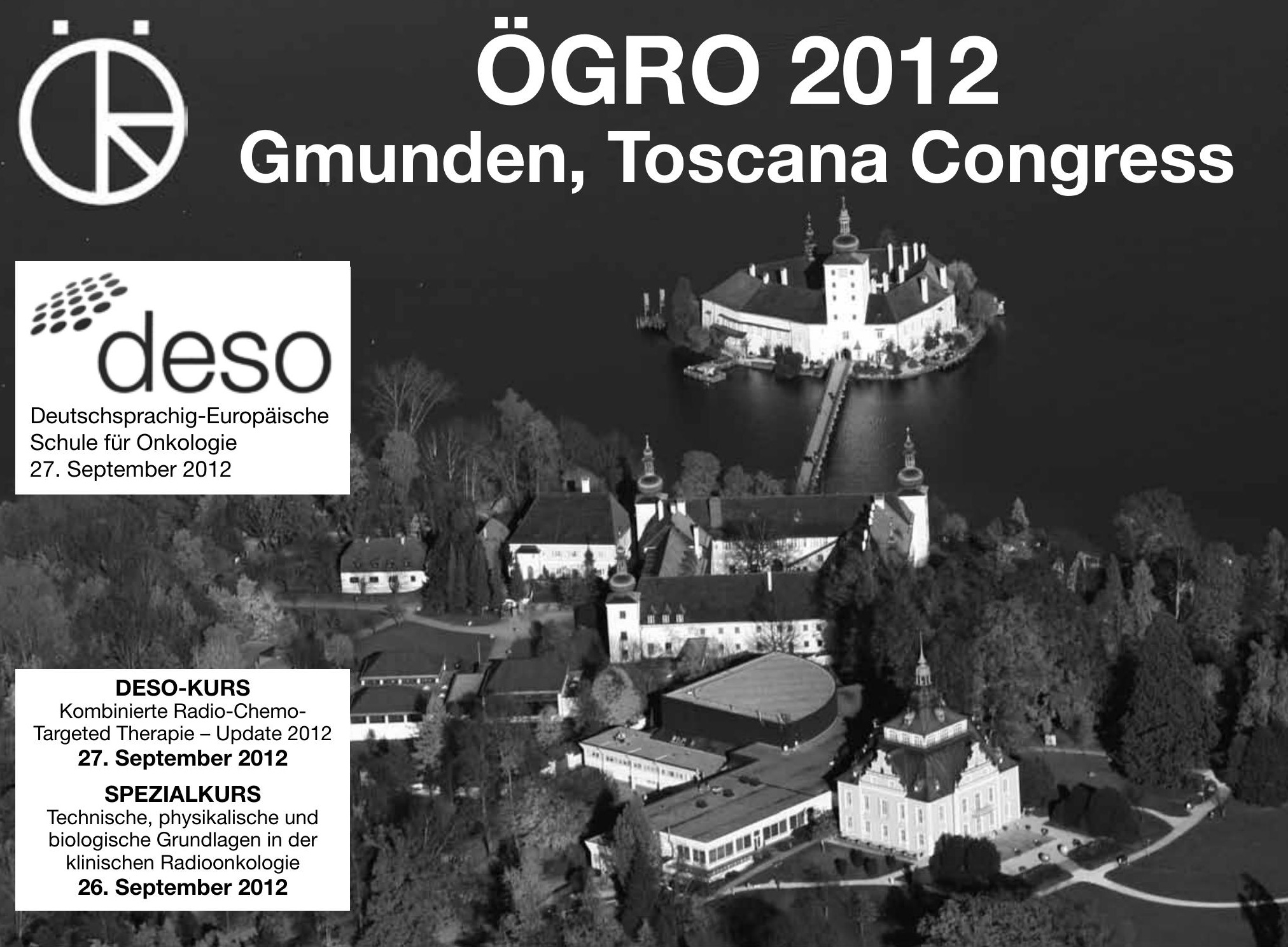

\section{Jahrestagung \\ 28. und 29. September 2012}

Veranstalter:

Österreichische Gesellschaft für Radioonkologie, Radiobiologie und Medizinische Radiophysik

Tagungspräsident:

Prim. Dr. Dietmar H. Seewald

TagungssekretärInnen:

Dr. Walpurga Stolz

Dr. Edith Kreuzbichler

\section{Assoziierte Veranstaltungen:}

DGKS-DGKP/RT-Symposium

\section{Organisation:}

Institut für Radio-Onkologie/Strahlentherapie LKH Vöcklabruck e-mail: radioonkologie.leitstelle.vb@gespag.at
ÖGRO:

„Hochtechnologie und menschliche Zuwendung"

Zukunft der Strahlentherapie in Österreich:

Photonen oder Protonen / Schwerionen?

Integration neuer Therapiekonzepte (Hypofraktio-

nierung, targeted therapy, Teilbrustbestrahlung)

Pulmonologische Tumore

Urogenitaltumore

Kolorektale Tumore

Sarkome

Palliativtherapie und supportive Maßnahmen

Komplementärmedizinische Maßnahmen

Benigne Erkrankungen

Freie Themen 


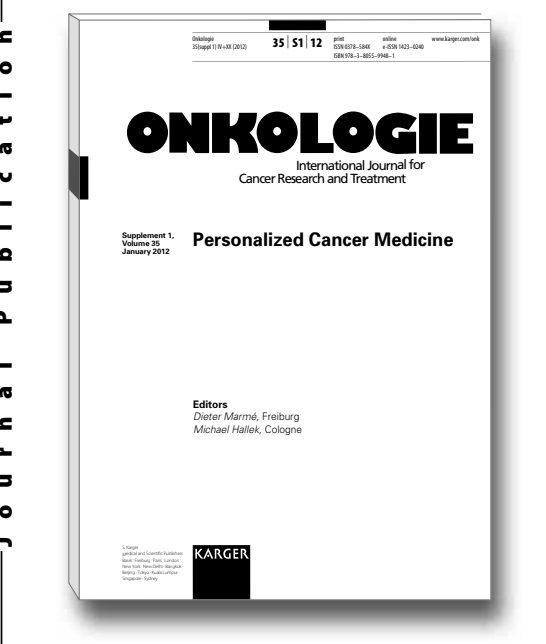

\title{
Personalized Cancer Medicine
}

\author{
Editors \\ Dieter Marmé \\ Michael Hallek
}

\section{Contents}

Editorial: Personalized Cancer Medicine: Marmé, D.; Hallek, $M$.

Personalized Therapy of Lung Cancer: Thomas, R.; Wolf, J.

Targeted Therapy of Soft Tissue

Sarcomas: Wardelmann, E.; Chemnitz, J.M.; Wendtner, $C .-M$.

Recent Developments and Future Perspectives of Personalized Oncology: Grüllich, C.; von Kalle, C.

Imatinib and Beyond - Targeting Activated Tyrosine Kinases in Myeloproliferative Disorders: Hochhaus, A.; Reiter, A.; Ernst, T.; La Rosée, $P$.

The Role of Molecular Diagnostics in Cancer Diagnosis and Treatment: Ozretić, L.; Heukamp, L.C.; Odenthal, M., Buettner, R.

Personalized Treatment of Colorectal Cancer: Arnold, D.; Stein, A.

Imprint

Personalized Therapy in Breast Cancer: Marmé, F.; Schneeweiss, A.

Personalized Cancer Medicine Editors: Marmé, D. (Freiburg i. Br.); Hallek, M. (Cologne) IV + 48 p., 13 fig., 12 in color, 7 tab., soft cover, 2012 CHF 44.- / EUR 37.- / USD 52.00

Prices subject to change

EUR price for Germany, USD price for USA only

ISBN 978-3-8055-9948-1

e-ISBN 978-3-8055-9949-8

\section{Supplement Issue}

Onkologie

Vol. 35, Suppl. 1 (2012)

Included in subscription

\section{Please send:__ copy/ies}

\section{$\varepsilon$}

Postage and handling free with prepayment

- Payment:

Please charge to my credit card

๑ $\square$ American Express $\square$ MasterCard $\square$ Visa

- Card No.

๑

Exp. date:

- CVV/CVC

( 3 digits in the signature field on the back of Visa and MasterCard)

$\square$ Please bill me

Orders may be placed with any bookshop, subscription agency, directly with the publisher or through a Karger distributor.
Fax: +49761 4520714

S. Karger Verlag für Medizin und Naturwissenschaften $\mathrm{GmbH}$ Wilhelmstrasse 20A, 79098 Freiburg (Germany)

E-Mail information@karger.de www.karger.de

Name/Address:

Date: 


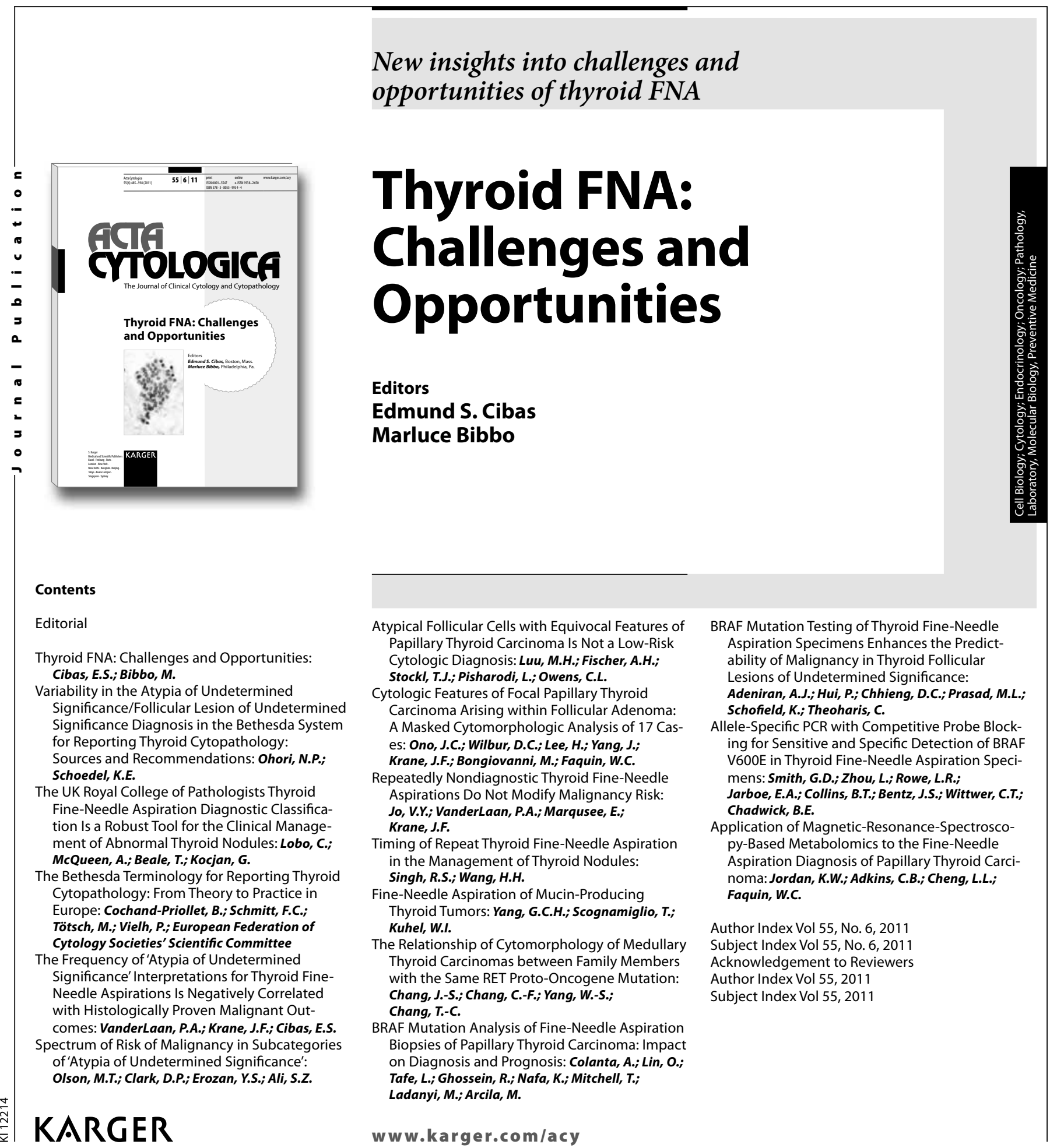

\section{Thyroid FNA: Challenges and} Opportunities

Editors: Cibas, E.S. (Boston, Mass.);

Bibbo, M. (Philadelphia, Pa.)

114 p., 34 fig., 24 in color, 44 tab., soft cover, 2011

CHF 39.- / EUR 33.- / USD 46.00

Prices subject to change

EUR price for Germany, USD price for USA only

ISBN 978-3-8055-9934-4

e-ISBN 978-3-8055-9935-1

Special Topic Issue:

Acta Cytologica

Vol. 55, No. 6 (2011)

Included in subscription

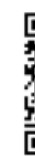

New insights into challenges and opportunities of thyroid FNA

\section{Edmund S. Cibas \\ Marluce Bibbo}

typical Follicular Cells with Equivocal Features of Cytologic Diagnosis: Luu, Stockl, T.J.; Pisharodi, L.; Owens, C.L. Arising within Follicular Adenoma: Masked Cytomorphologic Analysis of 17 CasKrane, J.F. Wang, H.H. Kuhel, W.I. ne Mutation: ossein, R.Nafa, K. Mitchell, $T$.

www.karger.com/acy
RAF Mutation Testing of Thyroid Fine-Needle ability of Malignancy in Thyroid Follicular Lesions of Undetermined Significance: Adeniran, A.J.; Hui, P.; Chhieng, D.C.; Prasad, M.L.; ofield, $K \cdot$; Theoharis, $C$

plock mens: Smith, G.D.; Zhou, L.; Rowe, L.R Jarboe, E.A.; Collins, B.T.; Bentz, J.S.; Wittwer, C.T.; wick, B.E.

py-Based Metabolomics to the Fine-Needle Aspiration Diagnosis of Papillary Thyroid Carcinoma: Jordan, K.W.; Adkins, C.B.; Cheng, L.L.;

Author Index Vol 55, No. 6, 2011 . Author Index Vol 55, 2011 Subject Index Vol 55, 201

\section{$\rightarrow$ Please send: ___ copy/ies}

Postage and handling free with prepayment

E

- Payment:

Please charge to my credit card

- $\square$ American Express $\square$ Diners

ᄂ $\square$ MasterCard $\square$ Visa

- Card No.

๑

ర Exp.date

- CVV/CVC

( 3 digits in the signature field on the back of Visa and MasterCard)

$\square$ Check enclosed $\square$ Please bill me

Orders may be placed with any bookshop, subscription agency, directly with the publisher or through a Karger distributor.
Fax: +41 613061234

S. Karger AG, P.O. Box, CH-4009 Basel (Switzerland) E-Mail orders@karger.ch,www.karger.com

Name/Address: 


\section{A single source for international hematology research and clinical practice since 1948}

\section{Acta Hæmatologica}

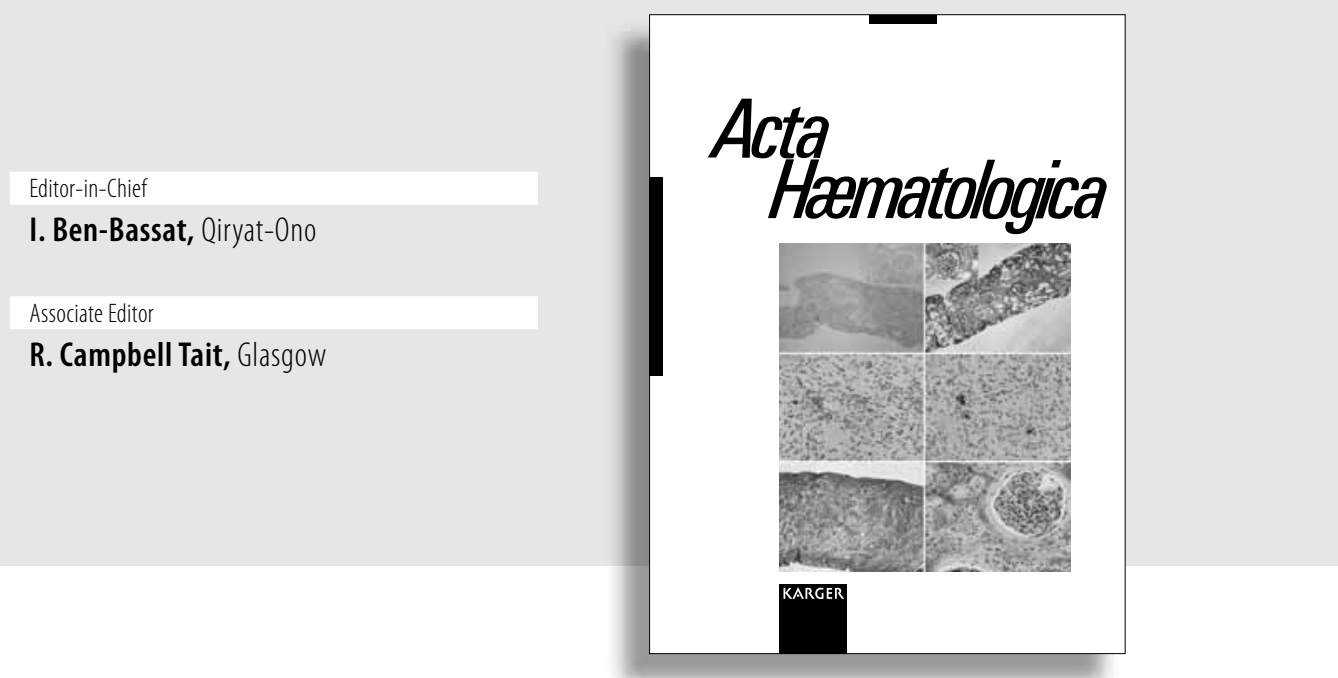

Acta Haematologica is a well-established and internationally recognized journal featuring balanced, wide-ranging coverage of current hematology research. A wealth of information on such problems as anemia, leukemia, lymphoma, multiple myeloma, hereditary disorders, blood coagulation, growth factors, hematopoiesis and differentiation is contained in first-rate basic and clinical papers. In particular, the journal has established itself as a special platform for noteworthy case reports of practical value to the clinical hematologist. These are supplemented by short state-of-the-art communications, reviews and correspondence as well as occasional special issues devoted to 'hot topics' in hematology.

\section{Selected contributions}

Bisphosphonates Induce Apoptosis of Circulating Endothelial Cells in Multiple Myeloma Patients and in Subjects with Bisphosphonate-Induced Osteonecrosis of the Jaws: Allegra, A.; Alonci, A.; Penna, G.; Granata, A.; Nastro Siniscalchi, E.; Oteri, G.; Loddo, S.; Teti, D.; Cicciù, D.; De Ponte, F.S.; Musolino, C. (Messina)

Clofarabine-Based Regimen as Useful Bridge Therapy for Allogeneic Transplantation in Myeloid Blast Crisis of Philadelphia-Positive Chronic Myeloid Leukemia Resistant to Imatinib and Dasatinib: Breccia, M.; Capria, S.; Iori, A.P.; Foà, R.; Alimena, G.; Meloni, G. (Rome)

Sorafenib Treatment in 13 Patients with Acute Myeloid Leukemia and Activating FLT3 Mutations in Combination with Chemotherapy or as Monotherapy: Schroeder, T. (Duesseldorf); Zohren, F. (Duesseldorf/Houston, Tex.); Saure, C.; Bruns, I. (Duesseldorf); Czibere, A. (Duesseldorf/Boston, Mass.); Safaian, N.N.; Fenk, R.; Haas, R.; Kobbe, G. (Duesseldorf)

Treatment of Patients with Multiple Myeloma: An Overview of Systematic Reviews: Kumar, A.; Galeb, S.; Djulbegovic, B. (Tampa, Fla.)

Meta-Analyses of Early-Stage Hodgkin Lymphoma: Herbst, C.; Engert, A. (Cologne) Twist and Shout: One Decade of Meta-Analyses of Erythropoiesis-Stimulating Agents in Cancer Patients: Bohlius, J.; Tonia, T. (Bern); Schwarzer, G. (Freiburg)

How Helpful Are Meta-Analyses in Determining the Best Therapy of Blood Diseases? Gale, R.P. (London); Lazarus, H.M. (Cleveland, Ohio)

Clinicopathologic Characteristics of CD99-Positive Diffuse Large B-Cell Lymphoma: Lee, S.P.; Park, S.; Park, J.; Hong, J. (Incheon); Ko, J.H. (Seoul)

The Significance of Bone Marrow Involvement in Aggressive Lymphomas: A Retrospective Comparison of Clinical Outcomes between Peripheral T Cell Lymphoma and Diffuse Large B Cell Lymphoma in China: Yi, S.; An, G.; Qi, J.; Zou, D.; Zhao, Y.; Zhang, P.; Chen, H. (Tianjin); Wang, J. (Loma Linda, Calif.); Qiu, L. (Tianjin)
More information at

\section{www.karger.com/aha}

- Pay-per-View and Subscriber Access to Full Text

- Full Table of Contents

- Full Editorial Board

- Free Abstracts and Selected Articles

- Online Sample Issue

- Submission/Guidelines for Authors

- Subscription Details

- Free Alert Service

- Online Library Recommendation

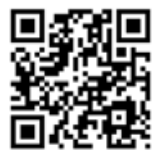

Acta Haematologica 2012: Volumes 127,128 4 issues per volume Language: English ISSN 0001-5792 (print) ISSN 1421-9662 (online)

Listed in bibliographic services, including Current Contents ${ }^{\oplus}$, MEDLINE, Biological Abstracts, EMBASE/Excerpta Medica 


\section{Oncology}

Clinical Studies

249 Metronomic Chemotherapy with the COMBAT Regimen in Advanced Pediatric Malignancies: A Multicenter Experience

Zapletalova, D. (Brno); André, N. (Marseille); Deak, L. (Košice); Kyr, M.; Bajciova, V.; Mudry, P.; Dubska, L.; Demlova, R.; Pavelka, Z.; Zitterbart, K.; Skotakova, J.; Husek, K.; Martincekova, A.; Mazanek, P.; Kepak, T.; Doubek, M.; Kutnikova, L.; Valik, D. (Brno); Sterba, J. (Brno/Marseille)

261 Elevated Neutrophil to Lymphocyte Ratio Predicts Poor Prognosis in Advanced Colorectal Cancer Patients Receiving Oxaliplatin-Based Chemotherapy

Kaneko, M.; Nozawa, H.; Sasaki, K.; Hongo, K.; Hiyoshi, M.; Tada, N.; Murono, K.; Nirei, T.; Kawai, K.; Sunami, E.; Tsuno, N.H.; Kitayama, J. (Tokyo)

275 A Critical Evaluation of the Preventive Effect of Antiviral Therapy on the Development of Hepatocellular Carcinoma in Patients with Chronic Hepatitis C or B: A Novel Approach by Using Meta-Regression Shen, Y.-C.; Hsu, C.; Cheng, C.-C.; Hu, F.-C.; Cheng, A.-L. (Taipei)
290 A Phase II Study of Clinical Outcomes of 3-Week Cycles of Irinotecan and S-1 in Patients with Previously Untreated Metastatic Colorectal Cancer: Influence of the UGT1A1 and CYP2A6 Polymorphisms on Clinical Activity Choi, Y.H.; Kim, T.W.; Kim, K.-P.; Lee, S.S.; Hong, Y.S.; Ryu, M.-H.; Lee, J.-L.; Chang, H.M.; Ryoo, B.-Y. (Seoul); Kim, H.-S.; Shin, J.-G. (Busan); Kang, Y.-K. (Seoul)

298 Clinical Benefit of High-Sensitivity KRAS Mutation Testing in Metastatic Colorectal Cancer Treated with Anti-EGFR Antibody Therapy

Kimura, T.; Okamoto, K.; Miyamoto, H.; Kimura, M.; Kitamura, S.; Takenaka, H.; Muguruma, N.; Okahisa, T.; Aoyagi, E.; Kajimoto, M. (Tokushima); Tsuji, Y.; Kogawa, T. (Sapporo); Tsuji, A. (Kochi); Takayama, T. (Tokushima)

Reducing the Worldwide Burden of Cancer

\section{Oncology in Cambodia}

Eav, S. (Phnom Penh); Schraub, S.; Dufour, P. (Strasbourg); Taisant, D. (Grenoble); Ra, C.; Bunda, P. (Phnom Penh) 